\title{
O CHIAR DOS CABELOS
}

\section{Ernesto Caminha ${ }^{1}$}

A casinha de taipa acomodava muito mal a família que não saíra de perto ante o falecimento do homem mais bruto que já aparecera por ali. O sol terminava de rachar os últimos pedaços do chão, ainda intactos, tal era a força de seu calor.

José jazia gemendo havia mais de mês sem nunca morrer; quando perguntavam a causa de sua prostração dizia com um protesto rancoroso que sofria da moléstia e cuspia sangue. A mãezinha não despregava o olho do filho enfermo e nem os dedos das bolinhas do rosário, que passavam pelo indicador e pelo dedão pelo menos quinze vezes ao dia. A ladainha da ave-maria não produzia som, apenas tremia-lhe os lábios que de onde às vezes saía um soprozinho seco.

Os irmãos não aguentavam mais. A mãe não fazia o mais o de comer, cuidando do filho mais velho e largando o terço somente para lhe passar o unguento sobre as feridas abertas no peito. Valfredo, Gerusa, filha de José que não tinha idade para cozinhar no forninho à lenha, Setembrino e Lindovaldo - esses dois últimos gêmeos ainda eram muito novos, não passavam dos vinte e cinco- moravam todos com Dona Juraci, saindo cedo, lá pelas cinco e tantas, para mó de trabalhar na roça. José, já não os acompanhava devido à doença que avançava invisível - foi confundida com uma simples gripe - havia tempo, base duns dois meses, um de precaução - não agravar o estado - outro de prostração. Todos aceitavam a condição de José, doente e precavido, e até certo tempo torciam por sua recuperação imediata - era um homem forte e ajudava demais à labuta dos irmãos -, até o ponto em que um médico chamado ao sítio, vindo de quase sete léguas de lonjura, dissera-lhes que o "quadro clínico era irreversível", impacientavam-se com o moribundo que teimava em não morrer, dava despesa e atrapalhava a rotina.

José jazia e, finalmente, morto, preparavam-lhe a cerimônia. Banharam-no, vestiram-lhe o terno que há muito havia comprado sob medida, gastando muito vintém, e

\footnotetext{
${ }^{11}$ Estudante de graduação em Filosofia pela Universidade de Brasília.
} 
deixaram-no sobre a mesma cama onde há algumas horas fedia à doente e onde, jazinha, jazinha, federia a defunto. Pobre José. Um homem duro demais consigo mesmo e com os outros de casa: brigão, irado, reto, justo, honesto, bobo. Cego de honestidade, às vezes passava-se por ingênuo. Os irmãosque mascavam e cuspiam fumo, assistiam à mãe colocar uma vela acesa entre os dedos do filho que repousavam no peito. Talvez estivessem arrependidos de terem desejado a morte do mano, vendo a aflição calada, resignada e dolorosa de Dona Juraci, que com um muxoxo constatou: "É a vontade de Deus". Fez um sinal da cruz, benzeu o filho morto e saiu para pitar.

Passavam das três da tarde. Será que a seca era assim, tão forte, a ponto de secar as lágrimas daquela velhinha? Ela deu o recado ao menino que foi avisar - a bordo de uma carroça - aos longínquos vizinhos que viessem velar José e, aos que não pudessem voltar naquela noite, que pernoitassem por lá, porque esteira não faltava e que voltassem no dia seguinte. Assim, de tardezinha, que o sol laranja lambia vermelho a palidez anêmica da caatinga, os primeiros enlutados se aproximavam e, assim que juntassem-se mais figurinhas como aquela que apontava no horizonte - esguias, vestindopreto da cabeça aos pés, encurvadas e enrugadas -, logo começariam as rezas e ladainhas fúnebres, um espetáculo.

Não demorou muito, e pela hora que a friagem sussurrava diabruras ao pé-doouvido, a casinha surrada de tabique surpreendentemente já abrigava para mais de trinta pessoas de sombras dançantes e difusas pelas chamas das velas trazidas pelas velhas ajudando a alumiar os rostos que, sob a fraca luz amarela que a lampinha de filamento espalhava pela salinha, ficavam irreconhecíveis.

As crianças corriam, a reza continuava, lenta e melancólica, quase um gemido uníssono se dispersando pelo imenso vazio e escuro do sítio. Gerusa corria como as outras - não as deixavam verem o morto - e, sem ninguém ver, esgueirou-se entre as pernas e vestidos e viu a cara de José, alumiada pela chama vermelha da vela que já havia sido trocada duas vezes, e que dava a seu rosto a terrível feição de um demônio vindo direto e reto do inferno. Ficou terrivelmente perturbada. Não lhe saía da cabeça a caretinha com chifres que a menina vira uma ou duas vezes, desenhada na bíblia da capelinha, onde ia mais a avó. Viu o algodão no nariz do pai e saiu correndo, coração palpitando na caixa do peito e, na cabeça, a certeza da condenação eterna - a avó falara-lhe do inferno. 
Arrodeou a tapera, abraçando seus joelhinhos magros cobertos por um paninho roto quando se sentou sob a janela que dava onde o defunto terminava de morrer. Ouvia a ladainha e repetia os versos que conhecia e tentava apagar a confusão que havia se tornado o rosto do homem e o do cramunhãozinho. Ouvia as matutas rezarem:

Gracioso Deus, por Teu poder nos deste a vida, e em teu amor tu nos dás nova vida em Cristo Jesus. Nós entregamos José aos Teus cuidados, pela fé em Jesus Cristo, Teu Filho, Nosso Senhor, que morreu e ressuscitou pra nos salvar; e nos trouxe a alegria da ressurreição e a glória do Teu reino eterno. Concede, Senhor, o Espírito de Consolação a nós que choramos. Amém.

A mocinha exclamava amém com fervor. O medo lhe descia em lágrimas. Levantou-se espiando o que acontecia pela janela e não viu a avó, nem os tios. Viu a beata que entoava o ofício de morte. Viu uma outra senhora achegar-se perto ao defunto e roçar-lhe o cabelo como cosia o rosário. Roçou e chegou o ouvido bem perto. "O cabelo inda chia. Não morreu inda não". Os olhinhos infantis arregalaram-se de tal maneira que talvez pudessem ter sido notados dentro do quartinho. Viram-na, realmente, e lhe fecharam a cortina na fuça.

Ave Maria, mãe de Deus...

Recomeçaram. Não queria dormir em casa essa noite. O terror de Gerusinha, não o sabia bem, mas o homem que ali inerte estava, que um dia fora seu pai e que agora trazia no semblante a cara de capeta vermelho, se se levantasse, iria pegá-la durante a noite: disso sabia. Maior foi seu susto, quando no outro dia - teimou, mas dormira por cansaço! - acordou cercada de gente estranha, menos de seu pai. Confirmou que o homem do cabelo que chiava, definitivamente havia levantado. Rezou como nunca. 